\title{
PENGARUH KEPUASAN KERJA, KOMPENSASI NON FINANSIAL, SERTA BUDAYA ORGANISASI TERHADAP RETENSI KARYAWAN
}

\author{
Diva Ditya Mersita Wandara ${ }^{1}$ \\ I Made Artha Wibawa ${ }^{2}$
}

\author{
${ }^{1,2}$ Fakultas Ekonomi dan Bisnis Universitas Udayana, Bali, Indonesia \\ email: divadityamw@gmail.com
}

\begin{abstract}
ABSTRAK
Tujuan penelitian ini untuk menjelaskan pengaruh kepuasan kerja, kompensasi non finansial serta budaya organisasi terhadap retensi karyawan. Penelitian ini dilakukan di PT. Bakas Aneka Citra Wisata Tirta dengan jumlah sampel yang digunakan sebanyak 79 orang karyawan, metode sampel jenuh dan pengumpulan data dilakukan melalui wawancara serta penyebaran kuesioner. Teknik analisis data yang digunakan adalah Uji Asumsi Klasik, Regresi Linier Berganda, Uji Ketepatan Model, dan Pengujian Hipotesis. Hasil dari penelitian ini menunjukan bahwa kepuasan kerja berpengaruh positif dan signifikan terhadap retensi karywan, selain itu kompensasi non finansial juga berpengaruh positif dan signifikan terhadap retensi karyawan, serta budaya organisasi yang berpengaruh positif dan signifikan terhadap retensi karyawan. Secara teoritis penelitian ini juga memberikan pemahaman bahwa dengan meningkatkan kepuasan kerja, kompensasi, serta budaya organisasi maka akan mampu mempertahankan karyawan untuk tetap tinggal diperusahaan.
\end{abstract}

Kata kunci: kepuasan kerja, kompensasi non finansial, budaya organisasi, retensi karyawan

\begin{abstract}
The purpose of this study is to explain the effect of job satisfaction, non-financial compensation and organizational culture on employee retention. This research was conducted at PT. Bakas Aneka Citra Wisata Tirta with a total sample of 79 employees, the saturated sample method and data collection were carried out through interviews and questionnaires. Data analysis techniques used are the Classic Assumption Test, Multiple Linear Regression, Model Accuracy Test, and Hypothesis Testing. The results of this study indicate that job satisfaction has a positive and significant effect on employee retention, in addition non-financial compensation also has a positive and significant effect on employee retention, and organizational culture has a positive and significant effect on employee retention. Theoretically this research also provides an understanding that by increasing job satisfaction, compensation, and organizational culture it will be able to retain employees to remain in the company.

Keywords: job satisfaction, non-financial compensation, organizational culture, employee retention
\end{abstract}




\section{PENDAHULUAN}

Perusahaan pada era globalisasi saat ini mengalami pertumbuhan yang sangat cepat di sisi lain persaingannya pun sangat ketat. Perusahaan harus mampu melakukan pemberdayaan atau pengembangan pada karyawannya untuk memenuhi kebutuhan dalam kesuksesan perusahaan. Sumber daya manusia merupakan faktor penting dalam kesuksesan suatu perusahaan dengan dapat menjalankan fungsi serta tujuannya guna untuk pencapaian yang di inginkan oleh perusahaan. peran dan fungsi SDM dapat dikelompokkan menjadi dua bagian, yaitu secara mikro dan makro. Secara mikro sumber daya manusia berperan dalam hal faktor produksi (ketenagakerjaan). Sedangkan secara makro peran sumber daya manusia dalam hal pembangunan dan kependudukan. Sumber Daya Manusia (SDM) merupakan suatu hal yang sangat penting dan harus dimiliki dalam upaya mencapai tujuan organisasi atau perusahaan. Sumber daya manusia merupakan elemen utama organisasi dibandingkan dengan elemen sumber daya yang lain seperti modal, teknologi, karena manusia itu sendiri yang mengendalikan faktor yang lain.

Manusia yang mempunyai kemampuan terpadu yang dicirikan dengan pola pikir dan daya fisik yang baik. Perilaku dan watak sumber daya manusia berasal dari lingkungannya sedangkan prestasi dan motivasi kerja berasal dari keinginan dirinya sendiri.

Sumber daya manusia juga merupakan aset yang berharga dalam perusahaaan sebagai pengagas keseluruhan dalam perusahaan. Sumber daya manusia memiliki peranan dan tugas yang penting bagi sebuah perusahaan demi mewujudkan tujuan. Segala masalah yang terjadi dalam perusahaan memiliki dampak yang sangat besar terhadap bertahannya karyawan. (Mathis \& Jackson, 2012), menyatakan bahawa retensi merupakan upaya untuk mempertahankan karyawan agar tetap berada dalam organisasi guna mencapai tujuan organisasi tersebut.

Demi mencapai tujuan sesuai dengan visi dan misi, perusahaan harus mampu mempertahankan karyawan dalam jangka waktu yang lama. (Swambawa Putra \& Rahyuda, 2016) menyatakan bahwa mempertahankan karyawan merupakan tugas dan tanggung jawab perusahaan itu sendiri.

Kinerja karyawan memiliki peranan penting bagi perusahaan, apabila kinerja yang ditampilkan karyawan rendah maka akan mengakibatkan perusahaan dalam mencapai tujuan menjadi terhambat (Ariana \& Riana, 2013). Berdasarkan fenomena yang terjadi tentunya tidak banyak perusahaan yang mampu mempertahankan karyawan dalam jangka waktu yang lama. Perusahaan yang mampu mempertahankan karyawan dalam jangka waktu yang lama tentu memiliki tingkat retensi karyawan yang tinggi. Salah satu perusahaan di Bali yang menjadi objek pada penelitian ini yaitu PT. Bakas Aneka Citra Wisata Tirta. Perusahaan ini merupakan perusahaan yang bergerak di bidang pariwisata di Bali dan telah menjadi perusahaan besar.

Untuk memenuhi tujuannya PT. Bakas Aneka Citra Wisata Tirta menyiapkan sumber daya manusia dengan kompetensinya masing-masing dimana di bagi menjadi berbagai jabatan yang ada di PT. Bakas Aneka Citra Wisata Tirta itu sendiri. Berdasarkan hasil wawancara awal dengan 8 orang karyawan tetap yang bekerja pada PT. Bakas Aneka Citra Wisata Tirta mereka menyatakan bahwa niat untuk bertahan di dalam perusahaan sangat tinggi namun ada beberapa faktor yang 
membuat karyawan harus mengundurkan diri dari perusahaan. Rata-rata karyawan meninggalkan perusahaan karena alasan akan menikah atau karena faktor umur, pekerjaan yang didapat tidak sesuai dengan kemampuan yang dimiliki, hingga fasilitas yang dirasa kurang sepadan dengan tugas yang di berikan oleh PT. Bakas Aneka Citra Wisata Tirta. Karyawan yang masih bertahan juga memaparkan bahwa pegawai yang mengundurkan diri karena adanya perbedaan budaya yang diterapkan oleh perusahaan itu sendiri contohnya seperti hanya memberikan libur hari raya besar agama tertentu hanya setengah dari hari libur yang semestinya dan juga budaya inovasi yang mendorong para anggota untuk menciptakan atau mengembangkan ide-ide kreatif dan inovatif demi kemajuan organisasi tersebut yang belum terealisasi dengan optimal. Oleh sebab itu setiap tahunnya tentu selalu ada pegawai atau karyawan yang mengundurkan diri karena merasa susah untuk ber adaptasi pada PT. Bakas Aneka Citra Wisata Tirta tersebut.

Tabel 1.

Data Karyawan PT. Bakas Aneka Citra Wisata Tirta Dari Tahun 2014 Sampai Dengan Tahun 2018

\begin{tabular}{cccccc}
\hline Tahun & $\begin{array}{c}\text { Karyawan } \\
\text { Awal }\end{array}$ & $\begin{array}{c}\text { Karyawan } \\
\text { Akhir }\end{array}$ & Rata-Rata & $\begin{array}{c}\text { Karyawan } \\
\text { Keluar }\end{array}$ & $\begin{array}{c}\text { LTO } \\
\text { \% }\end{array}$ \\
\hline $\mathbf{2 0 1 4}$ & 120 & 114 & 117 & 6 & 5,12 \\
$\mathbf{2 0 1 5}$ & 117 & 110 & 113,5 & 7 & 6,16 \\
$\mathbf{2 0 1 6}$ & 115 & 105 & 110 & 10 & 9,09 \\
$\mathbf{2 0 1 7}$ & 105 & 93 & 99 & 12 & 12,12 \\
$\mathbf{2 0 1 8}$ & 94 & 79 & 86.5 & 15 & 17,34 \\
\hline
\end{tabular}

Sumber: HRD PT. Bakas Aneka Citra Wisata Tirta, 2019

Tabel 1. menunjukkan bahwa persentase LTO (Labour Turn Over) pada PT. Bakas Aneka Citra Wisata Tirta selama 5 tahun terakhir mengalami labour turn over yang tinggi sedangkan tingkat retensi karyawan rendah setiap beberapa tahun sekali. Pada tahun 2018 menyentuh angka sebesar 17,34\%. Harris (2005), menyatakan bahwa standar tingkat turnover karyawan yang bisa ditolerir pada tiap perusahaan berbeda beda, namun jika tingkat turnover mencapai lebih dari 10\% per tahun adalah terlalu tinggi menurut banyak standar.

Retensi karyawan adalah teknik yang digunakan manajemen untuk mempertahankan karyawan agar tetap dalam perusahaan selama jangka waktu tertentu (Anggraeni \& Rasto, 2016). Mendefinisikan retensi merupakan upaya untuk mempertahankan karyawan agar tetap berada dalam organisasi guna mencapai tujuan organisasi tersebut. Retensi karyawan mengacu pada teknik yang digunakan oleh manajemen untuk membantu karyawan tetap dengan organisasi untuk jangka waktu yang lamaJika karyawan tidak dapat menggunakan potensinya dengan penuh dan tidak didengar atau dihargai ditempat mereka bekerja, mereka akan pergi karena stres dan frustasi (Oladapo, 2014). Kehilangan atau turnover karyawan, terutama dalam jumlah besar, merupakan kerugian besar bagi sebuah perusahaan. Apalagi jika karyawan tersebut adalah karyawan yang berbakat. Bukan hanya kehilangan sumber daya manusia, perusahaan juga akan mengalami penurunan produksi dan sumber finansial. Belum lagi, perusahaan harus mengeluarkan biaya ekstra untuk melakukan perekrutan dan pelatihan karyawan 
baru. Dengan rendahnya turnover karyawan maka perusahaan akan menghemat biaya - biaya salah satunya adalah biaya seleksi dan rekrutmen.

(Sedarmayanti, 2017) menyatakan seorang pegawai mampu melaksanakan kegiatannya dengan baik dan puas akan pekerjaannya, sehingga dicapai suatu hasil yang optimal, apabila ditunjang oleh suatu kondisi lingkungan kerja yang sesuai. Kepuasan kerja adalah keadaan emosional yang menyenangkan atau tidak menyenangkan dari para karyawan memandang pekerjaan mereka, (Handoko, 2011). Ketika karyawan memiliki perasaan yang positif mengenai perkerjaannya maka timbul rasa untuk tetap tinggal lebih lama di dalam perusahaan. Faktor kepuasan kerja juga menjadi poin penting yang harus dipenuhi. Seorang karyawan tentunya ingin memiliki kepuasan dalam melakukan pekerjaannya akan tetapi tidak jarang kepuasannya tidak dapat terpenuhi sebagaimana mestinya. Ketika karyawan merasakan kepuasan dalam bekerja maka karyawan tersebut akan bekerja dengan semaksimal mungkin. Individu yang merasa puas dengan pekerjaannya akan memiliki komitmen yang tinggi terhadap perusahaan dan keinginan untuk meninggakan perusahaan akan semakin rendah (Iqbal \& Iqbal, 2014).

Retensi karyawan erat kaitannya dengan program untuk pemeliharaan (maintenance), pemeliharaan tersebut dilakukan dengan sasaran kondisi fisik, mental, dan sikap loyal karyawan terhadap pekerjaannya. Program maintenance dapat berjalan dengan baik apabila dilakukan bersamaan dengan program pemberian kesejahteraan yang dibutuhkan oleh karyawan serta berpegang pada konsistensi internal dan eksternal dalam perusahaan dengan harapan meningkatkan retensi karyawan pada suatu perusahaan.Retensi karyawan adalah upaya perusahaan untuk mendorong karyawan yang berkompeten agar tetap bertahan untuk jangka waktu yang lama. Jika karyawan tidak dapat menggunakan potensinya dengan penuh dan juga tidak dihargai atau didengar di dalam tempat mereka bekerja, maka mereka akan keluar karena stres dan frustrasi. memelihara tingginya retensi karyawan akan meningkatkan efektifitas dan kinerja perusahaan karena dengan tingginya retensi, maka tentu saja turnover menjadi rendah. Memiliki tingkat retensi karyawan yang tinggi mampu mendorong mencapai tujuan perusahaannya.

Berdasarkan beberapa pengertian di atas, dapat disimpulkan bahwa retensi karyawan perputaran karyawan yang mengganggu kinerja perusahaan dan cukup memakan banyak biaya dan waktu untuk setiap organisasi. Berkaitan dengan upaya perusahaan untuk meminimalkan tingkat perputaran karyawan, manajemen memiliki tugas yang sangat penting, yakni menciptakan retensi karyawan karena karyawan bersifat aset perusahaan. Perusahaan lebih memilih mempertahankan karyawan daripada merekrut karyawan baru karena dengan memelihara retensi karyawan, perusahaan bisa meminimalkan biaya yang dikeluarkan untuk merekrut karyawan baru.

Adapun faktor penentu retensi karyawan dan juga faktor yang menjadi fokus utama pada variabel dalam penilitian ini yaitu dukungan organisasi yang mampu mempengaruhi retensi karyawan antara lain. 1) Lingkungan yaitu menciptakan dan meningkatkan tempat kerja yang lebih menarik, tetap memakai dan memelihara orang-orang yang bekerja dengan baik. 2) Hubungan yaitu bagaimana perusahaan dapat menyenangkan karyawan mereka dan juga menyenangkan antara yang satu 
dengan yang lain. 3) Dukungan organisasi, dimana meliputi pemberian peralatan perlengkapan yang dibutuhkan untuk menunjang pekerjaan karyawan dan juga informasi untuk melakukan pekerjaan dengan baik.

Peningkatan kepuasan kerja akan mempengaruhi kualitas kerja karyawan, dimana akan memiliki pengaruh yang baik terhadap pencapain tujuan perusahan (Awad, 1977). Meningkatkan kepuasan karyawan adalah kunci suksesnya organisasi bisnis, hal tersebut merupakan dasar bagi perusahaan untuk melihat seperti apa keinginan karyawan, lingkungan kerja yang diinginkan dan dengan hal tersebut akan dapat meningkatkan pengabdian karyawan (Bourguignons, 2016). Dengan tingginya kepuasan kerja dari karyawan di PT. Bakas Aneka Citra Wisata Tirta tentunya akan mampu meningkatkan ide-ide baru oleh karyawan untuk mengembangkan perusahaan tersebut.

Faktor yang dapat mempengaruhi kepuasan kerja karyawan pada dasarnya secara praktis dapat dibedakan menjadi dua kelompok, yaitu: faktor intrinsik dan faktor ektrinsik. Faktor intrinsik ialah faktor yang berasal dari diri karyawan dan dibawa oleh setiap karyawan sejak mulai bekerja ditempat pekerjaannya. Faktor ekstrinsik ialah menyangkut hal-hal yang berasal dari luar diri karyawan, antara lain kondisi fisik, lingkungan kerja, interaksi dengan karyawan lain, sistem penggajian, dan lain sebagainya. Dengan adanya kepuasan kerja yang tinggi dari para karyawan dalam suatu organisasi ataupun perusahaan, tentunya akan meningkatkan intensitas produktivitas yang baik bagi organisasi untuk kedepannya. Berdasarkan pengertian yang sudah dipaparkan di atas dapat diambil kesimpulan bahwa kepuasan kerja adalah sikap emosional sesorang yang positif atau negatif yang dihasilkan dari penilaian suatu pekerjaan atau pengalaman kerja.

Ada lima faktor yang dapat mempengaruhi kepuasan kerja, 1. Pemenuhan kebutuhan (Need fulfillment). Kepuasan ditentukan oleh tingkatan karakteristik pekerjaan memberikan kesempatan pada individu untuk memenuhi kebutuhannya, 2. Perbedaan (Discrepancies). Kepuasan merupakan suatu hasil memenuhi harapan. Pemenuhan harapan mencerminkan perbedaan antara apa yang diharapkan dan apa yang diperoleh individu dari pekerjaannya. Bila harapan lebih besar dari apa yang diterima, orang akan tidak puas. Sebaliknya individu akan puas bila menerima manfaat diatas harapan, 3. Pencapaian nilai (Value attainment). Kepuasan merupakan hasil dari persepsi pekerjaan memberikan pemenuhan nilai kerja individual yang penting, 4. Keadilan (Equity). Kepuasan merupakan fungsi dari seberapa adil individu diperlakukan di tempat kerja, 5. Komponen genetik (Genetic components). Kepuasan kerja merupakan fungsi sifat pribadi dan faktor genetik. Hal ini menyiratkan perbedaan sifat individu mempunyai arti penting untuk menjelaskan kepuasan kerja disampng karakteristik lingkungan pekerjaan.

Faktor yang mengikat tingkat retensi karyawan salah satunya adalah kompensasi. Tidak mengherankan karyawan yang dibayar lebih banyak merasa puas dengan pekerjaan mereka dan tidak cenderung meninggalkan atasan mereka. Kompensasi merupakan bentuk penghargaan yang diberikan kepada karyawan sebagai balas jasa atau kontribusi yang mereka berikan kepada organisasinya. Kompensasi merupakan imbalan yang diterima karyawan sebagai pengganti kontribusi jasa mereka pada perusahaan. Pemberian kompensasi merupakan salah satu pelaksanaan fungsi MSDM yang berhubungan dengan semua jenis pemberian 
penghargaan individual sebagai pertukaran dalam melaksanakan tugas keorganisasian (Nugraha \& Tjahjawati, 2018). Menurut (Prasodjo \& Setiawan, 2015), kompensasi dapat dibedakan menjadi kompensasi finansial dan kompensasi non finansial. Kompensasi non finansial terdiri dari program-program pelayanan bagi karyawan berkaitan dengan prestasi kerja dan juga barang tidak langsung yang diterima karyawan sebagai imbalan atas usaha atau jasa yang diberikan, (Hasibuan, 2018). Sebagian besar peneliti hanya berfokus pada aspek kompensasi finansial karena dianggap lebih bisa memberikan dampak yang lebih besar terhadap organisasi, namun dalam kenyataannya kompensasi non finansial pun memiliki peran kuat dalam mempertahankan niat karyawan untuk bertahan dalam suatu perusahaan.

Menurut (Rivai, 2005) Kompensasi non finansial terdiri atas karir yang meliputi jabatan, peluang promosi, pengakuan karya, pengakuan prestasi, pujian, bersahabat, kenyamanan saat bertugas, menyenangkan dan kondusif. Dengan adanya kompensasi yang adil dapat memicu partisipasi karyawan sehingga para karyawan dapat bekerja dengan penuh semangat serta tanggung jawab dan memiliki partisipasi kerja terhadap perusahaan (Sari, 2015). Kompensasi karyawan akan lebih semangat untuk bekerja (Astuti \& Sudharma, 2013). Sudah seharusnya setiap perusahaan menerapkan sistem yang benar dalam hal kompensasi khususnya kompensasi secara non finansial yang dimana kompensasi ini bisa di dapatkan setiap hari oleh karyawan pada PT. Bakas Aneka Citra Wisata Tirta.

Berdasarkan pengertian diatas dapat ditarik kesimpulan bahwa bukan hanya kompensasi secara finansial yang berperan aktif dalam mensejahterakan karyawan dalam organisasi, kompensasi non finansial pun memiliki pengaruh yang besar dalam mensejahterakan karyawan, kompensasi non finansial adalah sebuah balas budi ataupun jasa yang diberikan bukan dalam bentuk uang, tetapi seseorang akan memperoleh kepuasan dari pekerjaan, dan lingkungan organisasinya serta akan menguntungkan baik bagi perusahaan maupun karyawan. Dalam pemberian kompensasi non finansial juga harus melalui beberapa prosedur yang ada agar pemberian kompensasi tersebut dapat di rasakan adil oleh segala kalangan yang ada dalam organisasi tersebut.

Tujuan dan juga faktor dari pemberian kompensasi non finansial, 1) Bagi Perusahaan. Untuk meningkatkan produksi dengan cara mendorong mereka agar bekerja disiplin dan semangat yang lebih tinggi, serta dapat menggunakan faktor produksi dengan seefektif dan seefisien mungkin, 2) Bagi Karyawan. Agar karyawan memperoleh banyak keuntungan, seperti misalnya mendapat sesuatu yang lebih dan mendapat dorongan untuk mengembangkan dirinya dan berusaha bekerja sebaik-baiknya. Bagi organisasi, dengan pemberian kompensasi dapat meningkatkan produktivitas, disiplin dan semangat kerja pegawai. Sedangkan bagi pegawai pemberian kompensasi dapat mencapai sesuatu yang lebih berguna bagi dirinya serta dapat memotivasi diri untuk dapat mengembangkan diri sehingga mampu bekerja dengan sebaik mungkin.

Budaya organisasi secara sederhana dapat juga diartikan bagaimana segala sesuatu diselesaikan di tempat tersebut. Budaya dalam sebuah organisasi melibatkan sekumpulan pengalaman, filosofi, pengalaman, ekspektasi dan juga nilai yang terkandung di dalamnya yang nanti akan tercermin dalam perilaku 
anggota, mulai dari inner working,interaksi dengan lingkungan di luar organisasi, sampai ekpsktasi di masa depan. budaya organisasi adalah sebuah pola dari berbagai asumsi dasar yang ditemukan, diciptakan, atau dikembangkan oleh sebuah kelompok dengan tujuan agar organisasi belajar mengatasi dan menganggulangi masalah-masalah yang timbul akibat adaptasi eksternal dan integrasi internal yang sudah berjalan dengan cukup baik. Dengan begitu, budaya organisasi harus diajarkan kepada semua anggota baru sebagai cara yang benar untuk memahami, memikirkan, dan merasakan berkenaan dengan masalah-masalah tersebut.

Bertahannya karyawan di dalam perusahaan untuk jangka waktu yang panjang juga didukung dengan adanya budaya organisasi yang baik pada perusahaan PT. Bakas Aneka Citra Wisata Tirta. Budaya organisasi dapat menjadi sarana untuk menjaga agar karyawan tetap sejalan dan menyesuaikannya dengan tujuan organisasi (Omotayo, 2015). Semakin kuat budaya organisasi yang dianut, maka semakin tinggi juga tingkat kinerja karyawanya yang menandakan semakin baik kinerja karyawan maka semakin besar niat karyawan untuk bertahan dalam perusahaan untuk jangka waktu yang lama (Joushan, 2015).

Budaya organisasi mengandung unsur-unsur sebagai berikut, 1) Asumsi dasar. Ini berfungsi sebagai pedoman bagi anggota maupun kelompok dalam organisasi untuk berperilaku. 2) Keyakinan yang dianut. Keyakinan ini mengandung nilai-nilai yang dapat berbentuk slogan atau moto, asumsi dasar, tujuan umum organisasi/perusahaan, filosofi usaha, atau prinsip-prinsip menjelaskan usaha. 3) Pemimpin atau kelompok pencipta dan pengembang budaya organisasi. Budaya organisasi perlu diciptakan dan dikembangkan oleh pemimpin organisasi atau kelompok tertentu. 4) Pedoman mengatasi masalah. Terdapat dua masalah pokok yang sering muncul, yakni masalah adaptasi tersebut dapat diatasi dengan asumsi dasar dan keyakinan yang dianut bersama anggota organisasi. 5) Berbagai nilai (sharing of value). Perlu berbagi nilai terhadap apa yang paling diinginkan atau apa yang paling baik atau berharga bagi seseorang. 6) Pewarisan (Learning Process). Asumsi dasar dan keyakinan yang dianut perlu diwariskan kepada anggota-anggota baru dalam organisasi sebagai pedoman untuk bertindak dan berperilaku. 7) Penyesuaian (adaptation). Anggota kelompok perlu melakukan penyesuaian terhadap peraturan atau norma yang berlaku dalam kelompok atau organisasi tersebut, serta adaptasi organisasi terhadap perubahan lingkungan.

Budaya organisasi menjadi empat tipe utama berdasarkan dua dimensi yaitu sociability and solidarity. Keterhubungan didefinisikan sebagai tingkat keramahan dalam hubungan antara orang-orang dalam sebuah organisasi. Solidaritas adalah kemampuan orang untuk mengejar tujuan bersama secara efisien dan efektif demi kebaikan organisasi yang lebih besar tanpa memperhatikan dampaknya terhadap individu dan hubungan di antara mereka. Budaya organisasi dalam setiap organisasi memiliki berbedaannya masing-masing namun memiliki maksud dan tujuan yang sama dimana mencangkup tentang sikap, norma dan kepercayaan yang menyebabkan komunikasi yang kuat baik antara sesama karyawan maupun sebaliknya. Budaya organisasi adalah semua keyakinan, perasaan, perilaku, dan simbol-simbol yang mencirikan suatu perusahaan serta membedakan suatu perusahaan dengan perusahaan lainnya. 
Peran kepuasan kerja, kompensasi non finansial, dan budaya organisasi menjadi pertimbangan untuk perusahaan agar mampu mempertahakan karyawan untuk jangka waktu yang lama guna mencapai tujuan perusahaan. Dengan menjaga kepuasan kerja yang tinggi dari karyawan akan membantu perusahaan mencapai tujuannya dengan cepat. Dengan kompensasi yang relevan sesuai kinerja juga mampu mempengaruhi semangat kerja dari karyawan tersebut dan juga budaya organisasi yang kuat. Adanya pengaruh siginifikan hubungan antara kepuasan kerja terhadap retensi karyawan, karena semakin tingginya tingkat kepuasan kerja maka akan lebih rendahnya niat untuk keluarnya karyawan (Das, 2013). Kepuasan kerja memiliki pengaruh positif dan signifikan terhadap retensi karyawan, hal ini menunjukan perlu diperhatikan mengenai dukungan dari atasan maka retensi karyawan akan meningkat (Aditeresna \& Mujiati, 2018). Dimana semakin besar kepuasan kerja maka akan semakin tinggi retensi karyawan, dapat dikatakan karyawan yang puas memiliki niat yang lebih tinggi untuk bertahan dengan perusahaan (Astuti \& Sudharma, 2013). Oleh karena itu kepuasan kerja faktor terpenting yang harus diperhatikan. Penelitian lainnya menemukan bahwa kepuasan kerja berpengaruh terhadap retensi karyawan, karena ketika karyawan merasa puas terhadap pekerjaannya maka meningkatkan tingkat retensi (Motlou et al., 2016). Pengaruh dari kepuasan kerja terhadap karyawan memiliki hubungan yang erat kepuasan kerja yang dirasakan oleh karyawan menentukan mereka untuk keluar atau tetap bertahan di dalam perusahaan (Lusri \& Siagian, 2017). Hipotesis pertama ini mengartikan semakin tinggi tingkat kepuasan kerja maka tinggi pula retensi karyawan tersebut. Berdasarkan hasil penelitian sebelumnya, hipotesis yang dapat diajukan dalam penelitian ini adalah.

$\mathrm{H}_{1}$ : Kepuasan Kerja berpengaruh positif dan signifikan terhadap retensi karyawan.

Kompensasi yang bersifat non finansial, diberikan oleh organisasi atau perusahaan terutama dengan maksud mempertahankan karyawan dalam waktu yang lama (Leonardo \& Andreani, 2015). Kompensasi non-finansial dapat memotivasi karyawan untuk bekerja lebih baik dan juga mempertahankan karyawan untuk waktu yang lama (Wulan Permata Sari et al., 2016). Penelitian lainnya juga menemukan bahwa kompensasi non finansial sebagai faktor penting serta mendominasi retensi karyawan (Permana, 2015). Penelitian selanjutnya mengatakan bahwa balas jasa yang tidak berupa uang mempunyai manfaat tidak bisa dirasakan secara langsung oleh karyawan yang mampu meningkatkan niat bertahan karyawan (Hidayati \& Saputra, 2018). Peneliti lain menemukan adanya signifikansi kompensasi non finansial yang berupa kepuasan yang diterima seseorang dari pekerjaan itu sendiri atau dari lingkungan psikologis dan atau fisik tempat orang tersebut bekerja yang mempengaruhi niat bertahan dalam perusahaan (Tiwi, 2018). Hipotesis dua ini berarti semakin tinggi kompensasi yang diterima maka semakin tinggi retensi karyawan tersebut. Berdasarkan hasil penelitian sebelumnya, hipotesis yang dapat diajukan dalam penelitian ini adalah.

$\mathrm{H}_{2}$ : Kompensasi non finansial berpengaruh positif dan signifikan terhadap retensi karyawan.

Berbagai alasan yang dikutip mengenai keputusan karyawan untuk bertahan adalah budaya organisasi, dukungan dari rekan kerja dan atasan, peluang pertumbuhan, masalah yang berkaitan dengan kompensasi, kegiatan keterlibatan 
karyawan, pelatihan dan pengembangan, lingkungan kerja positif dan kondisi kerja yang baik (Pousette et al., 2014). Joushan et al. , 2015), menyatakan bahwa semakin kuat budaya organisasi yang dianut, maka semakin tinggi juga tingkat kinerja karyawanya yang menandakan semakin baik niat karyawan untuk bertahan dalam perusahaan untuk jangka waktu yang lama. Adanya hubungan dari budaya organisasi yang mampu menahan karyawan untuk tetap tinggal lebih lama serta mampu meningkatkan motivasi diri untuk bekerja lebih baik (Kerja et al., 2018). Ketika budaya organisasi diterapkan dengan baik di dalam perusahaan maka akan meningkatkan retensi karyawan (Wibawa, 2019). (Fachreza \& Said Musnadi, 2018) menerima kesimpulan bahwa budaya organisasi dan lingkungan kerja berperan penting dalam memastikan retensi karyawan dalam perusahaan. Hipotesis ketiga semakin kuat budaya organisasi yang ada maka semakin tinggi retensi karyawan tersebut.

$\mathrm{H}_{3}$ : Budaya organisasi berpengaruh positif dan signifikan terhadap retensi karyawan

\section{METODE PENELITIAN}

Penelitian ini menggunakan pendekatan kuantitatif yang bersifat asosiatif untuk meneliti data yang bersifat statistik serta menguji suatu hipotesis, dengan kuesioner sebagai instrumen yang dipakai. Hal ini dikarenakan terdapat hubungan kausal (sebab-akibat) antara variabel bebas (X1, X2 dan X3) yaitu kepuasan kerja, kompensasi non finansial dan budaya organisasi dengan variabel terikat (Y) yaitu retensi karyawan.

Lokasi penelitian bertempat di PT. Bakas Aneka Citra Wisata Tirta dengan alamat kantor di Desa Sanur, Denpasar-Bali. Untuk lokasi wahana bertempat di Dusun Kawan, Desa Bakas, Kec. Banjarangkan, Kabupaten Klungkung. Alasan yang melatar belakangi peneliti melakukan penelitian di PT. Bakas Aneka Citra Wisata Tirta adalah adanya akses yang memudahkan peneliti untuk mendapatkan informasi yang dibutuhkan dalam penelitian ini. Subyek dalam penelitian ini adalah seluruh karyawan pada PT. Bakas Aneka Citra Wisata Tirta yang terdiri dari divisi marketing, divisi operasional, divisi HRD, divisi keuangan, divisi villa. Objek dalam penelitian ini adalah (1) Kepuasan Kerja, (2) Kompensasi Non Finansial, (3) Budaya Organisasi, dan (4) Retensi Karyawan PT. Bakas Aneka Citra Wisata Tirta.

Populasi dari penelitian ini adalah seluruh karyawan PT. Bakas Aneka Citra Wisata Tirta yang berjumlah 79 orang. Metode yang digunakan dalam penentuan sampel adalah metode nonprobability sampling yang didalamnya terdapat metode sampling jenuh, yaitu dimana semua anggota populasi digunakan sebagai sampel penelitian. Seperti yang sudah terlampir pada tabel dalam penelitian ini adalah seluruh karyawan PT. Bakas Aneka Citra Wisata Tirta yang berjumlah 79 orang.

Metode regresi linier berganda digunakan dalam penelitian ini untuk mengetahui pengaruh Kepuasan Kerja $\left(\mathrm{X}_{1}\right)$, Kompensasi Non Finansial $\left(\mathrm{X}_{2}\right)$ dan Budaya Organisasi $\left(\mathrm{X}_{3}\right)$ Retensi Karyawan $(\mathrm{Y})$. metode ini diuji menggunakan sistem komputer berupa spss. Pengaruh variabel bebas terhadap variabel terikat 
diuji dengan tingkat kepercayaan 95\% atau $\alpha=5 \%$. Model regresi yang digunakan adalah sebagai berikut.

$\mathrm{Y}=\alpha+\beta_{1} \mathrm{X}_{1}+\beta_{2} \mathrm{X}_{2}+\beta_{3} \mathrm{X}_{3}+\ldots . .+\mathrm{e}$

Keterangan:

$\mathrm{Y}=$ Retensi Karyawan

$\mathrm{X}_{1}=$ Kepuasan Kerja

$\mathrm{X}_{2}=$ Kompensasi Non Finansial

$\mathrm{X}_{3}=$ Budaya Organisasi

$\alpha=$ Konstanta

$\beta_{1}=$ Koefisien regresi Kepuasan Kerja

$\beta_{2}=$ Koefisien regresi Kompensasi Non Finansial

$\beta_{3}=$ Koefisien regresi Budaya Organisasi

$\mathrm{e}=$ eror

\section{HASIL DAN PEMBAHASAN}

Data karakteristik responden adalah data responden yang dikumpulkan untuk mengetahui profil responden penelitian. Berdasarkan hasil penelitian yang dilakukan terhadap karyawan PT. Bakas Aneka Citra Wisata Tirta dapat diketahui karakteristik respondennya meliputi jenis kelamin, usia dan pendidikan terakhir yang dijelaskan pada Tabel 2 .

Tabel 2.

Karakteristik Responden PT. Bakas Aneka Citra Wisata Tirta

\begin{tabular}{|c|c|c|c|c|}
\hline No & Variabel & Klasifikasi & $\begin{array}{l}\text { Jumlah } \\
\text { (orang) }\end{array}$ & $\begin{array}{c}\text { Persentase } \\
(\%)\end{array}$ \\
\hline \multirow{4}{*}{1} & Jenis & Laki - Laki & 44 & 55,70 \\
\hline & Kelamin & Perempuan & 35 & 44,30 \\
\hline & & Jumlah & 79 & 100 \\
\hline & \multirow{4}{*}{ Usia } & 18-24 Tahun & 8 & 10,13 \\
\hline \multirow{3}{*}{2} & & 25-34 Tahun & 34 & 43,04 \\
\hline & & 35-40 Tahun & 24 & 30,38 \\
\hline & & $>$ 40Tahun & 3 & 3,80 \\
\hline \multirow{5}{*}{3} & \multirow{5}{*}{$\begin{array}{c}\text { Pendidikan } \\
\text { terakhir }\end{array}$} & Jumlah & 79 & 100 \\
\hline & & SMA & 10 & 12,66 \\
\hline & & Diploma & 32 & 40,51 \\
\hline & & $\mathrm{S} 1$ & 27 & 34,18 \\
\hline & & Jumlah & 79 & 100 \\
\hline
\end{tabular}

Sumber: Data diolah, 2019

Berdasarkan Tabel 2. menunjukkan jumlah karyawan PT. Bakas Aneka Citra Wisata Tirta yang di jadikan sampel sebanyak 79 orang. Jika di lihat dari jenis kelamin, jenis kelamin laki-laki mendominasi dalam penelitian ini dengan persentase sebesar 55,70 persen. Jika di lihat dari usia, yang memiliki usia 25-34 tahun mendominasi dengan presentase sebesar 43,04 persen. Jika di lihat dari tingkat pendidikan yang memiliki tingkat pendiddikan terakhir Diploma yang mendominasi dengan persentase sebesar 40,51 persen. 
Model analisis regresi linear berganda digunakan untuk mendapat koefisien regresi yang akan menentukan apakah hipotesis yang dibuat akan diterima atau ditolak. Hasil analisis ini mengacu pada hasil pengaruh variabel kepuasan kerja $\left(\mathrm{X}_{1}\right)$, variabel Kompensasi non finansial $\left(\mathrm{X}_{2}\right)$ variabel Budaya organisasi $\left(\mathrm{X}_{3}\right)$ terhadap Retensi karyawan (Y) PT. Bakas Aneka Citra Wisata Tirta Adapun hasil analisis regresi dengan program Statitical Pacage of Social Science (SPSS) versi 21.0 for Windows dapat dilihat pada Tabel 3. berikut.

Tabel 3.

Rangkuman Hasil Analisis Regresi Linear Berganda

\begin{tabular}{|c|c|c|c|c|c|}
\hline \multirow[b]{2}{*}{ Model } & \multicolumn{2}{|c|}{$\begin{array}{l}\text { Unstandardized } \\
\text { Coefficients }\end{array}$} & \multirow{2}{*}{$\begin{array}{c}\text { Standardized } \\
\text { Coefficients } \\
\text { Beta } \\
\end{array}$} & \multirow[t]{2}{*}{$\mathbf{t}$} & \multirow[t]{2}{*}{ Sig. } \\
\hline & B & Std. Error & & & \\
\hline (Constant) & 0,318 & 0,247 & & 1,285 & 0,203 \\
\hline kepuasan kerja & 0,306 & 0,095 & 0,301 & 3,230 & 0,002 \\
\hline $\begin{array}{l}\text { Kompensasi } \\
\text { finansial }\end{array}$ & 0,283 & 0,098 & 0,294 & 2,892 & 0,005 \\
\hline Budaya organisasi & 0,331 & 0,096 & 0,338 & 3,461 & 0,001 \\
\hline
\end{tabular}

Sumber: Data diolah, 2019

Berdasarkan Tabel 3. dapat ditulis persamaan regresi linear berganda sebagai berikut.

$$
Y=0,318+0,306 X_{1}+0,283 X_{2}+0,331 X_{3}
$$

Dimana :

$$
\begin{aligned}
& \mathrm{Y}=\text { Retensi karyawan } \\
& \mathrm{X}_{1}=\text { Kepuasan kerja } \\
& \mathrm{X}_{2}=\text { Kompensasi non finansial } \\
& \mathrm{X}_{3}=\text { Budaya organisasi }
\end{aligned}
$$

Persamaan regresi linear berganda tersebut menunjukkan arah masingmasing variabel bebas terhadap variabel terikatnya. Persamaan regresi linear berganda tersebut dapat diuraikan sebagai berikut :

Nilai constant 0,318 menunjukan apabila Kepuasan Kerja, Kompensasi Non Finansial dan Budaya Organisasi bernilai sama dengan 0 (nol) maka Retensi Karyawan PT. Bakas Aneka Citra Wisata Tirta bernilai sebesar 0,318

$\mathrm{X}_{1}=0,306$ menunjukkan bahwa Kepuasan kerja berpengaruh positif terhadap Retensi karyawan PT. Bakas Aneka Citra Wisata Tirta , apabila kepuasan kerja meningkat maka Retensi karyawan akan mengalami peningkatan, begitu pula sebaliknya. $\mathrm{X}_{2}=0,283$, menunjukkan bahwa Kompensasi non finansial berpengaruh positif terhadap Retensi karyawan PT. Bakas Aneka Citra Wisata Tirta , apabila Kompensasi non finansial karyawan meningkat maka Retensi karyawan akan mengalami peningkatan, begitu pula sebaliknya. $\mathrm{X}_{3}=$ 0,331, menunjukkan bahwa Budaya organisasi berpengaruh positif terhadap Retensi karyawan PT. Bakas Aneka Citra Wisata Tirta, apabila Budaya organisasi karyawan meningkat maka Retensi karyawan akan mengalami peningkatan, 
begitu pula sebaliknya.Model regresi dikatakan model yang baik apabila dalam model tersebut bebas dari asumsi klasik statistik. Suatu model regresi linear berganda secara teoritis akan menghasilkan nilai parameter penduga yang tepat bila memenuhi persyaratan asumsi klasik regresi, yaitu: uji normalitas, multikolinearitas, dan heteroskedastisitas.

Pada penelitian ini pengujian normalitas dilakukan menggunakan analisis analisis statistik One-Sample Kolmogorov-Smirnov, yaitu dengan membandingkan Kolmogorov-Smirnov hitung dengan Kolmogorov-Smirnov tabel. One-Sample Kolmogorov-Smirnov pada uji non parametrik.Adapun hasil uji One-Sample Kolmogorov-Smirnov dapat ditampilkan dalam Tabel 4.

Tabel 4.

Uji Normalitas (One-Sample Kolmogorov-Smirnov)

\begin{tabular}{lr}
\hline & \multicolumn{2}{c}{$\begin{array}{c}\text { Unstandardized } \\
\text { Residual }\end{array}$} \\
\hline N & 79 \\
Kolmogorov-Smirnov Z & 1,262 \\
Asymp. Sig. (2-tailed) & 0,083 \\
\hline Sumber: Datt dion 2019
\end{tabular}

Sumber: Data diolah, 2019

Berdasarkan uji normalitas dengan menggunakan One-Sample KolmogorovSmirnov Test yang ditampilkan pada Tabel 4. tersebut menunjukkan bahwa besarnya nilai Kolmogorov-Smirnov adalah sebesar 0,083. Nilai KolmogorovSmirnov tersebut lebih besar dibandingkan dengan nilai Kolmogorov-Smirnov tabel sebesar 0,05 maka $\mathrm{H}_{\mathrm{o}}$ diterima yang mengindikasikan bahwa data yang digunakan pada penelitian ini terdistribusi normal, sehingga dapat disimpulkan bahwa model memenuhi asumsi normalitas.

Uji multikolinearitas dilakukan untuk melihat apakah terdapat korelasi yang sempurna antar variabel bebas yang digunakan pada penelitian ini. Pengujian multikolinearitas dilakukan dengan menganalisis nilai tolerance dan nilai VIF. Nilai tolerance dan nilai VIF digunakan untuk mengukur variabilitas variabel independen atau hubungan antar variabel independen, jika nilai tolerance kurang dari 0,10 atau nilai VIF lebih dari 10 maka menunjukkan adanya multikolinearitas. Adapun nilai tolerance dan nilai VIF ditunjukkan pada Tabel 5. berikut:

Tabel 5.

Uji Multikolinieritas (Tolerance dan Variance Inflation Factor)

\begin{tabular}{lrr}
\hline \multicolumn{1}{c}{ Variabel } & \multicolumn{2}{c}{ Collinearity Statistics } \\
\cline { 2 - 3 } & Tolerance & VIF \\
\hline Kepuasan kerja & 0,477 & 2,096 \\
Kompensasi non finansial & 0,402 & 2,488 \\
Budaya organisasi & 0,434 & 2,304 \\
\hline Sumber: Data diolah, 2019 & &
\end{tabular}

Berdasarkan Tabel 5. tersebut ditunjukkan bahwa tidak terdapat variabel bebas yang memiliki nilai tolerance kurang dari 0,10 dan juga tidak ada variabel bebas yang memiliki nilai VIF lebih dari 10. Maka dari pada itu model regresi bebas dari gejala multikoleniaritas. 
Pengujian heteroskedastisitas diakukan melalui metode glesjer dan dengan grafik scatterplot. Metode glesjer meregresikan model regresi untuk mendapatkan nilai residualnya, kemudian nilai residual tersebut diabsolutkan dan dilakukan regresi dengan semua variabel independen. Bila terdapat variabel independen yang berpengaruh secara signifikan terhadap residual absolut maka terjadi heteroskedastisitas pada model regresi ini.Tabel 6. menunjukkan hasil perhitungan statistik dengan metode glesjer.

\section{Tabel 6.}

\section{Uji Heteroskedastisitas (Uji Glesjer)}

Coefficients(a)

\begin{tabular}{llrrrr}
\hline \multicolumn{1}{c}{ Variabel } & \multicolumn{2}{c}{$\begin{array}{c}\text { Unstandardized } \\
\text { Coefficients } \\
\text { Std. Error }\end{array}$} & $\begin{array}{c}\text { Standardized } \\
\text { Coefficients } \\
\text { Beta }\end{array}$ & t & Sig. \\
& B & 0,172 & & 2,238 & 0,028 \\
\hline (Constant) & 0,386 & 0,066 & 0,050 & 0,300 & 0,765 \\
kepuasan kerja & 0,020 & 0,068 & 0,001 & 0,005 & 0,996 \\
Kompensasi non & 0,000 & 0,067 & $-0,044$ & $-0,252$ & 0,801 \\
finansial & $-0,017$ & & & &
\end{tabular}

Berdasarkan Tabel 6. tersebut, ditunjukkan bahwa masing-masing model memiliki nilai signifikansi lebih besar dari 5\%. Hal ini menunjukkan bahwa variabel bebas yang digunakan pada penelitian ini tidak berpengaruh secara signifikan terhadap variabel terikatnya yaitu absolute error, maka dari itu, penelitian ini bebas dari gejala heteroskedastisitas.

Analisis derteminasi dilakukan untuk mengetahui sejauh mana variasi variabel bebas yaitu $\mathrm{X}_{1}$ (Kepuasan kerja), $\mathrm{X}_{2}$ (Kompensasi non finansial) dan $\mathrm{X}_{3}$ (Budaya organisasi) terhadap variabel Retensi karyawan (Y). berdasarkan hasil spss yang dapat dilihat pada Tabel 7 .

Tabel 7.

Analisis Determinasi

\begin{tabular}{lrrrr}
\hline Model & R & R Square & Adjusted $R$ Square & $\begin{array}{c}\text { Std. Error of the } \\
\text { Estimate }\end{array}$ \\
\hline 1 & $0,830^{\mathrm{a}}$ & 0,689 & 0,677 & 0,56887 \\
\hline
\end{tabular}

Sumber: Data diolah, 2019

Berdasarkan Tabel 7. tersebut dapat diketahui bahwa nilai $R$ square $\left(R^{2}\right)=$ 0,689 Adapun analisis menggunakan rumus sebagai berikut:

$$
\begin{aligned}
& D=r^{\wedge} 2 \times 100 \% \ldots . \\
& D=0,689 \times 100 \% \\
& D=68,9 \%
\end{aligned}
$$

Berdasarkan hasil tersebut diketahui bahwa nilai $\mathrm{R}^{2}=68,9$ persen, yang berarti bahwa sebesar 68,9 persen Retensi karyawan PT. Bakas Aneka Citra Wisata Tirta dipengaruhi oleh variabel kepuasan kerja (X1) ,Kompensasi non finansial (X2), dan Budaya organisasi (X3) dan sisanya sebesar 31,1 persen dipengaruhi oleh variabel lain yang tidak dimasukan dalam model penelitian ini. 
Uji F digunakan untuk mengetahui apakah secara serempak (simultan) seluruh variabel bebas (variabel Kepuasan kerja, variabel Kompensasi non finansial variabel Budaya organisasi) memiliki pengaruh terhadap variabel terikat (Retensi karyawan). Tabel 9. menunjukkan hasil perhitungan uji $\mathrm{F}$ dengan menggunakan SPSS 21.

Tabel 9.

Hasil Uji F

\begin{tabular}{llrrrrr}
\hline Model & & Sum of Squares & Df & Mean Square & F & Sig. \\
\hline \multirow{4}{*}{1} & Regression & 53,758 & 3 & 17,919 & 55,373 & $0,000^{\mathrm{b}}$ \\
& Residual & 24,271 & 75 & 0,324 & & \\
& Total & 78,029 & 78 & & & \\
\hline
\end{tabular}

Sumber: Data diolah, 2019

Berdasarkan hasil analisis, diketahui nilai signifikansi $\mathrm{F}$ adalah $0,000<0,05$, maka $\mathrm{H}_{0}$ ditolak. Hal ini berarti bahwa variabel Kepuasan kerja $\left(\mathrm{X}_{1}\right)$, variabel Kompensasi non finansial $\left(\mathrm{X}_{2}\right)$, variabel Budaya organisasi $\left(\mathrm{X}_{3}\right)$, secara simultan berpengaruh signifikan terhadap retensi karyawan (Y) PT. Bakas Aneka Citra Wisata Tirta, atau model yang digunakan dalam penelitian layak dan dapat dipergunakan untuk analisis berikutnya.

Uji parsial (uji t) digunakan untuk menguji pengaruh masing-masing variabel bebas (variabel Kepuasan kerja, variabel Kompensasi non finansial , variabel Budaya organisasi) terhadap variabel terikat (Retensi karyawan). Tabel 10 menunjukkan hasil perhitungan uji t dengan menggunakan SPSS 21.

Tabel 10.

Hasil Uji t

\begin{tabular}{lrr}
\hline Variabel & Unstandardized Coefficients Beta & Sig. \\
\hline Kepuasan kerja & 0,306 & 0,002 \\
Kompensasi non finansial & 0,283 & 0,005 \\
Budaya organisasi & 0,331 & 0,001 \\
\hline
\end{tabular}

Sumber: Data diolah, 2019

Berdasarkan hasil analisis di atas dapat dijelaskan bahwa tingkat signifikansi $0,002<0,05$, sehingga $\mathrm{H}_{0}$ ditolak dan $\mathrm{H}_{\mathrm{a}}$ diterima yang berarti bahwa variabel Kepuasan kerja berpengaruh positif signifikan terhadap Retensi karyawan. Koefisien regresi $\beta 1$ (variabel Kepuasan kerja) sebesar 0,306, menunjukkan bahwa meningkatnya Kepuasan kerja maka akan meningkatkan Retensi karyawan PT. Bakas Aneka Citra Wisata Tirta.

Berdasarkan hasil analisis di atas dapat dijelaskan bahwa tingkat signifikansi $0,005<0,05$, sehingga $\mathrm{H}_{0}$ ditolak dan $\mathrm{H}_{\mathrm{a}}$ diterima yang berarti bahwa variabel Kompensasi non finansial berpengaruh positif signifikan terhadap Retensi karyawan. Koefisien regresi $\beta_{2}$ (variabel Kompensasi non finansial) sebesar 0,283, menunjukkan bahwa meningkatnya Kompensasi non finansial maka akan meningkatkan Retensi karyawan PT. Bakas Aneka Citra Wisata Tirta .

Berdasarkan hasil analisis di atas dapat dijelaskan bahwa tingkat signifikansi $0,001<0,05$, sehingga $\mathrm{H}_{0}$ ditolak dan $\mathrm{H}_{\mathrm{a}}$ diterima yang berarti bahwa variabel Budaya organisasi berpengaruh positif signifikan terhadap Retensi karyawan. 
Koefisien regresi $\beta_{3}$ (variabel Budaya organisasi ) sebesar 0,331, menunjukkan bahwa meningkatnya Budaya organisasi maka akan meningkatkan Retensi karyawan PT. Bakas Aneka Citra Wisata Tirta

Pengolahan data SPSS menyatakan bahwa terdapat pengaruh positif dan signifikan antara Kepuasan kerja terhadap Retensi karyawan PT. Bakas Aneka Citra Wisata Tirta. Koefisien variabel $\mathrm{X}_{1}$ adalah positif artinya kepuasan kerja berpengaruh positif terhadap Retensi karyawan. Hal ini ditunjukan oleh indikator $\mathrm{X}_{1.1}$ dimana perusahaan tempat responden bekerja memberikan pekerjaan atau jobdesc yang sesuai dengan kemampuan masing-masing individu sehingga responden mampu memaksimalkan hasil kerja yang di inginkan oleh perusahaan dan dengan sesuainya kemampuan serta pekerjaan yang dilakukan hal ini juga dapat menjadi faktor responden untuk tetap tinggal di perusahaan. Indikator lain yaitu $\left(\mathrm{X}_{1.4}\right)$ dimana perusahaan harus terus melatih setiap karyawannya untuk bisa menjalin hubungan yang baik dengan sesame karyawan karena dengan terjalin hubungan yang baik antara sesama karyawan akan menimbulkan lingkungan kerja yang kondusif. Selanjutnya melihat dari karakteristik responden dimana di dominasi oleh jenis kelamin laki-laki dengan usia yang mendominasi 25-34 serta pendidikan terakhir yang mendominasi yakni diploma perusahaan sudah seharusnya menggunakan sumber daya tersebut dengan semaksimal mungkin dengan usia yang sedang produktif untuk mencapai tujuan dari perusahaan dengan cara meningkatkan kepuasan kerja dari para karyawan sehingga karyawan dapat dan mampu bekerja dengan optimal.

Hasil penelitian ini mengembangkan penelitian yang dilakukan oleh (Das, 2013) menyatakan bahwa adanya pengaruh siginifikan hubungan antara kepuasan kerja terhadap retensi karyawan, karena semakin tingginya tingkat kepuasan kerja maka akan lebih rendahnya niat untuk keluarnya karyawan. Kepuasan kerja memiliki pengaruh positif dan signifikan terhadap retensi karyawan, hal ini menunjukan perlu diperhatikan mengenai dukungan dari atasan maka retensi karyawan akan meningkat (Aditeresna \& Mujiati, 2018). Dimana semakin besar kepuasan kerja maka akan semakin tinggi retensi karyawan, dapat dikatakan karyawan yang puas memiliki niat yang lebih tinggi untuk bertahan dengan perusahaan (Astuti \& Sudharma, 2013). Oleh karena itu kepuasan kerja faktor terpenting yang harus diperhatikan. Penelitian lainnya menemukan bahwa kepuasan kerja berpengaruh terhadap retensi karyawan, karena ketika karyawan merasa puas terhadap pekerjaannya maka meningkatkan tingkat retensi (Motlou et al., 2016). Pengaruh dari kepuasan kerja terhadap karyawan memiliki hubungan yang erat kepuasan kerja yang dirasakan oleh karyawan menentukan mereka untuk keluar atau tetap bertahan di dalam perusahaan (Lusri \& Siagian, 2017)

Pengolahan data SPSS menyatakan bahwa terdapat pengaruh positif dan signifikan antara Kompensasi non finansial terhadap Retensi karyawan PT. Bakas Aneka Citra Wisata Tirta. Koefisien variabel $\mathrm{X}_{2}$ adalah positif kompensasi non finansial berpengaruh positif terhadap Retensi karyawan. Hal ini ditunjukan oleh indikator $\mathrm{X}_{2.4}$ dimana pembagian kerja di perusahaan tempat responden bekerja memberikan pembagian pekerjaan yang jelas terhadap masing-masing responden sehingga tidak melebihi kapasitas jabatan yang di emban oleh setiap responden oleh sebab itu akan menimbulkan niat untuk bertahan di perusahaan menjadi lebih lama. 
Hasil penelitian ini mengembangkan penelitian yang dilakukan oleh (Pousette et al., 2014) yang menyatakan kompensasi non-finansial dapat memotivasi karyawan untuk bekerja lebih baik dan juga mempertahankan karyawan untuk waktu yang lama. Penelitian lainnya juga menemukan bahwa kompensasi non finansial sebagai faktor penting serta mendominasi retensi karyawan (Permana, 2015). Penelitian selanjutnya mengatakan bahwa balas jasa yang tidak berupa uang mempunyai manfaat tidak bisa dirasakan secara langsung oleh karyawan yang mampu meningkatkan niat bertahan karyawan (Hidayati \& Saputra, 2018). Peneliti lain menemukan adanya signifikansi kompensasi non finansial yang berupa kepuasan yang diterima seseorang dari pekerjaan itu sendiri atau dari lingkungan psikologis dan atau fisik tempat orang tersebut bekerja yang mempengaruhi niat bertahan dalam perusahaan (Tiwi, 2018).

Pengolahan data SPSS menyatakan bahwa terdapat pengaruh positif dan signifikan antara budaya organisasi terhadap retensi karyawan PT. Bakas Aneka Citra Wisata Tirta. Koefisien variabel $\mathrm{X}_{3}$ adalah positif budaya organisasi berpengaruh positif terhadap retensi karyawan. Hal ini ditunjukan oleh salah satu indikator $\mathrm{X}_{3.1}$ dimana timbul keinginan dari dalam diri masing-masing responden untuk ikut memperhatikan secara detail segala permasalahan yang mungkin timbul dan dapat merugikan perusahaan tempat responden bekerja, dengan melatih tumbuhnya niat tersebut maka dapat menimbulkan niat bertahan di perusahaan bagi responden menjadi tinggi. Indikator lainnya yaitu $\left(\mathrm{X}_{3.2}\right)$ dimana perusahaan harus memberi pelatihan dan masukan kepada masing-masing karyawan untuk mau dan ikut memberi perhatian lebih kepada setiap masalah yang terjadi. Selanjutnya indikator $\left(\mathrm{X}_{3.4}\right)$ sudah seharusnya perusahaan menerapkan budaya ikut andil dan menghormati semua kepentingan anggota organisasi, dengan menerapkan budaya tersebut nantinya setiap karyawan akan mampu mencontoh sikap perusahaan tersebut dan akan menimbulkan kesadaran dari setiap individu karyawannya.

Hasil penelitian ini mengembangkan penelitian yang dilakukan oleh (Joushan et al., 2015) menyatakan bahwa semakin kuat budaya organisasi yang dianut, maka semakin tinggi juga tingkat kinerja karyawanya yang menandakan semakin baik niat karyawan untuk bertahan dalam perusahaan untuk jangka waktu yang lama. Adanya hubungan dari budaya organisasi yang mampu menahan karyawan untuk tetap tinggal lebih lama serta mampu meningkatkan motivasi diri untuk bekerja lebih baik (Kerja et al., 2018). Ketika budaya organisasi diterapkan dengan baik di dalam perusahaan maka akan meningkatkan retensi karyawan (Swambawa Putra \& Rahyuda, 2016). (Pousette et al., 2014) Menerima kesimpulan bahwa budaya organisasi dan lingkungan kerja berperan penting dalam memastikan retensi karyawan dalam perusahaan.

\section{SIMPULAN}

Kepuasan kerja berpengaruh positif dan signifikan terhadap retensi karyawan PT. Bakas Aneka Citra Wisata Tirta. Kompensasi non finansial berpengaruh positif dan signifikan terhadap retensi karyawan PT. Bakas Aneka Citra Wisata Tirta. 
Budaya Organisasi berpengaruh positif dan signifikan terhadap retensi karyawan PT. Bakas Aneka Citra Wisata Tirta.

Secara praktis, pihak manajemen PT. Bakas Aneka Citra Wisata Tirta harus tetap mempertahankan kepuasan kerja, kompensasi non finansial dan budaya organisasi di dalam perusahaan agar karyawan merasa puas dan dapat berkomitmen terhadap perusahaan, sehingga akan meningkatkan retensi karyawan PT. Bakas Aneka Citra Wisata Tirta. Hal yang Harus ditingkatkan adalah dari segi kepuasan kerja adalah hubungan antara rekan kerja memiliki rata-rata terendah hal ini harus ditingkatkan lagi agar karyawan merasa semangat dalam bekerja dengan memberikan acara yang dapat menjalin hubungan antara karyawan agar seluruh karyawan memiliki hubungan yang baik. Dari segi kompensasi non finansial hal yang perlu ditingkatkan adalah penghargaan yang setimpal dengan kinerja karyawan adapun hal yang dapat dilakukan adalah dengan memberikan penghargaan yang setimpal terhadap prestasi yang dimiliki oleh karyawan. Dari segi motivasi hal yang perlu ditingkatkan adalah berorientasi terhadap hasil dengan cara memberikan pemahamaan tetntang budaya organisasi yang ada diperusahaan tentang tujuan perusahaan agar karyawan merasa mereka menjadi satu kesatuan dalam suatu organisasi.

Bagi peneliti selanjutnya, diharapkan pada peneliti selanjutnya tidak berpaku pada faktor-faktor dalam penelitian ini yaitu kepuasan kerja, motivasi dan kompensasi non finansial, namun dapat menambah faktor-faktor lain yang mungkin mempengaruhi Retensi karyawan. Selain itu, peneliti selanjutnya diharapkan dapat menambahkan atau menggunakan penelitian lain terkait dengan industri dan teknik analisis yang berbeda.

\section{REFERENSI}

Aditeresna, K. A. R., \& Mujiati, N. W. (2018). Pengaruh Kompensasi, Kepuasan Kerja Dan Pengembangan Karir Terhadap Retensi Karyawan di KUTABEX HOTEL. E-Jurnal Manajemen Universitas Udayana. v07.i11.p01

Anggraeni, R., \& Rasto, R. (2016). Job Satisfaction and Organizational Commitment as Determinants of Teacher Performance.

Ariana, I., \& Riana, I. (2013). Pengaruh Kepemimpinan, Kompensasi dan Displin Kerja Terhadap Kinerja Karyawan Pada Hotel Cendana Resort \& Spa Ubud, Gianyar. E-Jurnal Manajemen Universitas Udayana.

Astuti, N., \& Sudharma, I. (2013). Pengaruh Kompensasi Dan Motivasi Terhadap Kepuasan Dan Kinerja Karyawan Pada Hotel Bakung's Beach Cottages KutaBali. E-Jurnal Manajemen Universitas Udayana.

Awad, E. M. (1977). Job satisfaction as a predictor of tenure. Proceedings of the 1977 Annual Conference, ACM 1977, 7(1), 206-210. 
Bourguignons, A. (2016). Abj' M. 4(2).

Das, B. L. (2013). Employee Retention: A Review of Literature. IOSR Journal of Business and Management, 14(2), 08-16.

Fachreza., Said Musnadi., dan M. S. A. M. (2018). Pengaruh Motivasi Kerja, Lingkungan Kerja, dan Budaya Organisasi Terhadap Kinerja Karyawan dan Dampaknya Pada Kinerja Bank Aceh Syariah di Kota Banda Aceh. Jurnal Magister Manajemen.

Handoko, T. H. (2011). Manajemen Personalia dan Sumber Daya Manusia. Pengantar Manajemen.

Hasibuan. (2018). Manajemen Sumber Daya Manusia. In Manajemen Sumber Daya Manusia.

Hidayati, S. N., \& Saputra, S. D. (2018). Pengaruh Kepemimpinan, Kompensasi, Komunikasi, dan Motivasi Kerja terhadap Turnover Intention Pegawai dengan Kepuasan Kerja sebagai "Variabel Antara." Jurnal Maksipreneur: Manajemen, Koperasi, Dan Entrepreneurship, 7(2), 162.v7i2.365

Iqbal, N., \& Iqbal, N. (2014). Human Epidermal Growth Factor Receptor 2 (HER2) in Cancers: Overexpression and Therapeutic Implications. Molecular Biology International.

Joushan, Shindie Aulia, Syamsul, Muhammad , Kartika, L. (2015). Pengaruh Budaya Organisasi dan Employee Engagement terhadap Kinerja Karyawan pada PT PLN ( Persero ) Area Bekasi. Jurnal Aplikasi Manajemen, 13(66), 697-703.

Kerja, P. L., Karyawan, P., Kepuasan, D. A. N., Terhadap, K., \& Nurisman, H. (2018). Retensi Karyawan Generasi Y Di Pt Pamapersada Nusantara. 27(02), 26-37.

Leonardo, E., \& Andreani, F. (2015). Pengaruh Pemberian Kompensasi Terhadap Kinerja Karyawan Pada PT. Kopanitia. Geophysical Research Letters.

Lusri, L., \& Siagian, H. (2017). Pengaruh Motivasi Kerja Terhadap Kinerja Karyawan Melalui Kepuasan Kerja Sebagai Variabel Mediasi Pada Karyawan Pt . Borwita Citra Prima Surabaya. Agora.

Mathis, R. L., \& Jackson, J. H. (2012). Human resource management: Manajemen sumber daya manusia. In Terjemahan Dian Angelia. Jakarta: Salemba Empat.

Motlou, R. G., Singh, S., \& Karodia, A. M. (2016). An Evaluation of the Impact of 
Diva Ditya Mersita Wandara, Pengaruh Kepuasan Kerja...

Job Satisfaction on Employee Retention At Lonmin Rowland Shaft North West Province. Kuwait Chapter of Arabian Journal of Business and Management Review.

Nugraha, A., \& Tjahjawati, S. S. (2018). Pengaruh Kompensasi Terhadap Kinerja Karyawan. Jurnal Riset Bisnis Dan Investasi.

Oladapo, V. (2014). The impact of talent management on retention. Journal of Business Studies Quarterly.

Omotayo, F. O. (2015). Knowledge Management as an important tool in Organisational Management: A Review of Literature. Library Philosophy and Practice.

Permana, M. (2015). PENGARUH KOMPENSASI FINANSIAL DAN KOMPENSASI NON FINANSIAL TERHADAP TURNOVER INTENTION (Studi Pada Karyawan PT. PLN (Persero) APJ Malang). Jurnal Administrasi Bisnis S1 Universitas Brawijaya.

Pousette, A., Larsman, P., Hemlin, S., Kauth, M. R., Sullivan, G., Blevins, D., Cully, J. A., Landes, R. D., Said, Q., Teasdale, T. A., Boasberg, J., The Department of Education, Academy, T., Academy, R., Trakt, S. S., Quinot, G., Liebenberg, S., Miller JC, I. I. I., Walton, T. F., ... Logan, J. (2014).分析 Title. Implementation Science, 39(1), 1-15.

Prasodjo, R. K., \& Setiawan, R. (2015). Pengaruh Kompensasi Finansial Dan Non Finansial. Program Manajemen Bisnis, Program Studi Manajemen, Universitas Kristen Petra Jl.

Rivai, V. (2005). Manajemen Sumber Daya Manusia Untuk Perusahaan : dari Teori ke Praktik. In Edisi Pertama, Penerbit PT. Raja Grafindo Persada, Jakarta.

Sari, E. L. (2015). Pengaruh Pemberian Kompensasi Terhadap Produktivitas Kerja Karyawan Pada Pt Ryan Jaya Persada. Jurnal Ilmu Dan Riset Manajemen.

Sedarmayanti. (2017). Manajemen Sumber Daya Manusia. In Manajemen Sumber Daya Manusia.

Swambawa Putra, I., \& Rahyuda, A. (2016). Pengaruh Kompensasi, Lingkungan Kerja dan Perceived Organizational Support (POS) Terhadap Retensi Karyawan. E-Jurnal Manajemen Universitas Udayana.

Tiwi, M. L. (2018). Pengaruh Kompensasi Finansial Dan Non Finansial Terhadap Turnover Intention Pada Karyawan Bidang Produksi Pt . Tunas Hijau Di Tabang, Kutai Kartanegara. 6(3), 1165-1179. 
Wibawa, I. M. A. (2019). CITIZENSHIP BEHAVIOR PADA KARYAWAN Fakultas Ekonomi dan Bisnis Universitas Udayana ( Unud ), Bali , Indonesia Sumber daya manusia merupakan hal yang sangat penting dalam suatu perusahaan maupun organisasi karena keefektifan dan keberhasilan suatu perusaha. 8(1), 7340-7370.

Wulan Permata Sari, G. A., Leli Kusuma Dewi, L. G., \& Eka Mahadewi, N. P. (2016). Pengaruh Kompensasi Finansial Dan Kompensasi Non- Finansial Terhadap Kinerja Karyawan Pada Pt. Angkasa Pura I (Persero) Bandar Udara Internasional Ngurah Rai Bali. Jurnal IPTA, 4(2), 82.v04.i02.p17 